\title{
SEJARAH DAN FIKSI DALAM DUA NOVEL KARYA KWEE TEK HOAY: SEBUAH TINJAUAN SASTRA SEJARAH
}

\author{
THE HISTORY AND FICTION IN TWO NOVELS \\ BY KWEE TEK HOAY: A HISTORICAL LITERATURE STUDY
}

\author{
Irna Gayatri D. Ardiansyah \\ Gopher Indonesia \\ Graha Induk KUD Lantai 2, Jalan Warung Buncit Raya No. 18--20, Jakarta \\ Pos-el: irnagayatri@gmail.com
}

\begin{abstract}
This research aims at analyzing the history and fiction in two novels by Kwee Tek Hoay. The researcher searches for some information from library and website resources to support this research. Specifically, the researcher searches for library resources containing information about the literature of Chinese Malay. The researcher analyzes Atsal Mulahnya Timbul Pergerakan Tionghoa and Berkahnya Malaise by using qualitative method. Bassically, the two novels present the history, i.e. Malaise event on Berkahnya Malaise and the origin of Hwee Koan community movement on Atsal Mulahnya Timbul Pergerakan Tionghoa. However, there is a fiction appeared from author's idea on the two novels. The idea comes in the form of communication presented between literature and the readers.
\end{abstract}

Keywords: history, fiction, Kwee Tek Hoay literature, Chinese Malay literature

\begin{abstract}
Abstrak
Tulisan ini akan menguraikan sejarah dan fiksi dalam dua novel karya Kwee Tek Hoay. Penulis mencari berbagai informasi dari berbagai sumber pustaka dan sumber dalam jaringan untuk mendukung penelitian ini. Secara lebih khusus, penulis mencari sumber pustaka yang menyajikan informasi seputar kesusastraan Melayu Tionghoa. Penulis menganalisis Atsal Mulahnya Timbul Pergerakan Tionghoa dan Berkahnya Malaise dengan menggunakan metode penelitian kualitatif. Kedua novel tersebut pada dasarnya memang menyajikan sejarah, yaitu peristiwa malaise dalam Berkahnya Malaise dan asal mula dibentuknya perkumpulan atau pergerakan Tionghoa Hwee Koan dalam Atsal Mulahnya Timbul Pergerakan Tionghoa. Akan tetapi, terdapat pula fiksi yang berupa gagasan pengarang dalam kedua novel tersebut. Gagasan tersebut merupakan bentuk komunikasi yang disajikan pengarang antara karya sastra dengan pembaca.
\end{abstract}

Kata kunci: sejarah, fiksi, sastra Kwee Tek Hoay, sastra Melayu Tionghoa

\section{Pendahuluan}

Karya sastra dianggap sebagai karya sastra yang baik ketika kritikus sastra mengategorikannya sebagai karya sastra yang bernilai. Itulah yang terjadi dalam kesusastraan Indonesia modern. Kritikus yang berperan terhadap perkembangan kesusastraan Indonesia 
modern, seperti H.B. Jassin dan Sutan Takdir Alisjahbana, memang telah membentuk paradigma pembaca mengenai karya sastra yang bernilai tersebut.

Kesusastraan Indonesia modern dianggap baru muncul pada 1920, yaitu ketika novel Azab dan Sengsara karya Merari Siregar diterbitkan dan diterima secara luas oleh pembaca (Sumardjo, 2004: 9). Karya-karya terbitan Balai Pustaka lainnya akhirnya dianggap pula sebagai sastra Indonesia modern dengan peran kritikus sastra di dalamnya. Karya sastra yang dikenal sampai saat ini serta selalu muncul dalam buku pelajaran sekolah tingkat dasar sampai dengan menengah atas adalah karya sastra yang sama yang berasal dari penulis yang sama. Dua di antaranya yang tentu paling dikenal adalah Chairil Anwar dengan puisi "Aku" dan Marah Rusli dengan novel Siti Nurbaya.

Karya-karya sastra Melayu Tionghoa tidak mengalami nasib yang sama. Pemakaian istilah sastra Melayu Tionghoa ditemukan belakangan dan digunakan untuk menyebut karya-karya sastra yang ditulis oleh orang-orang Tionghoa peranakan. Akan tetapi, pemakaian istilah tersebut dewasa ini paling tidak telah memberikan ruang bagi karya-karya tersebut dalam kesusastraan Indonesia. Karya-karya sastra Tionghoa peranakan tersebut sekarang sudah mulai diterbitkan lagi dengan pengantar mengenai karya-karya, sastrawan, dan polemik kesusastraan tersebut.

Karya-karya sastra Melayu Tionghoa dalam kenyataannya mencapai jumlah yang tidak terduga. Jakob Sumardjo mencatat terdapat 3.005 karya yang ditulis oleh 806 penulis Tionghoa peranakan. Dari ratusan penulis tersebut, salah satu yang banyak menyumbangkan karyanya adalah Kwee Tek Hoay, sebagaimana telah dikatakan oleh Salmon yang dikutip oleh Wahyudi (dalam Sidharta, 2001: xxv), yang telah menghasilkan 115 judul buku. Sementara itu, menurut Sumardjo (1989: 97), Kwee Tek Hoay setidaknya telah menghasilkan 25 karya.

Kwee Tek Hoay banyak menulis karya yang kontekstual atau mengikuti zamannya. Sumardjo (1989: 120) menyebutkan bahwa Kwee Tek Hoay adalah sastrawan kontekstual. Karyakaryanya ditulis sebagai hasil kepekaannya terhadap kejadian atau peristiwa penting di sekitarnya. Dia menulis Drama dari Krakatau, Drama dari Merapi, Korbannya Yi Yung Toan, Drama di Boven Digoel, Berkahnya Malaise, dan Atsal Mulahnya Timbul Pergerakan Tionghoa yang Modern di Indonesia sebagai bentuk ketanggapannya terhadap peristiwaperistiwa tersebut.

Karena karya-karya tersebut merupakan hasil tanggapan Kwee Tek Hoay terhadap peristiwa yang terjadi di sekitarnya, akan ditemukan pula fakta sejarah di dalamnya. Dua di antaranya yang akan penulis analisis dalam makalah ini adalah Atsal Mulahnya Timbul Pergerakan Tionghoa yang Modern di Indonesia (berikutnya disingkat AMTPTMI) dan Berkahnya Malaise.

AMTPTMI selesai ditulis pada 31 Desember 1908 dan diterbitkan pertama kali dalam majalah Moestika Romans pada 1933. Sesuai dengan judulnya, AMTPTMI mengisahkan asal mula pergerakan Tionghoa yang modern dibentuk. Pergerakan modern yang dimaksud adalah Tiong Hoa Hwee Koan (selanjutnya disingkat THHK). Sementara itu, Berkahnya Malaise diterbitkan pada 1933-1935 dalam bentuk kolom mingguan di majalah Moestika Romans. Novel ini terdiri atas 23 bab yang berisi 23 cerita dari orang yang berbeda. Adapun yang diceritakan 
dalam novel ini adalah berkah yang didapatkan karena peristiwa malaise.

Dua novel tersebut memberikan banyak informasi mengenai peristiwa dan organisasi yang ada di dalamnya, yaitu malaise dan THHK. Dalam makalah ini penulis akan menunjukkan bagian-bagian yang merupakan informasi atau fakta sejarah dan bagian-bagian yang merupakan fiksi atau gagasan pengarang. Ini dapat membuktikan pula bahwa Kwee Tek Hoay adalah sastrawan yang kontekstual, seperti yang dikatakan oleh Jakob Sumardjo.

Berdasarkan latar belakang tersebut, penulis merumuskan masalah penelitian sebagai berikut.

1. Mana sajakah sejarah dan fiksi dalam AMTPTMI dan Berkahnya Malaise?

2. Apakah peran dan pengaruh latar belakang pengarang dalam penulisan dan penggabungan dua unsur tersebut?

Berdasarkan dua masalah tersebut, penulis memiliki tujuan penelitian sebagai berikut.

1. Menunjukkan unsur sejarah dan fiksi yang terdapat dalam AMTPTMI dan Berkahnya Malaise.

2. Menjelaskan peran dan pengaruh latar belakang pengarang dalam kedua novel tersebut.

Penelitian ini bermanfaat untuk memberikan gambaran mengenai sejarah dalam sastra. Secara lebih khusus, penelitian ini bermanfaat untuk memberikan pengetahuan baru mengenai sejarah dan fiksi dalam AMTPTMI dan Berkahnya Malaise. Selain itu, penelitian ini juga bermanfaat sebagai data untuk penelitian-penelitian berikutnya yang berhubungan dengan Kwee Tek Hoay dan karyanya, khususnya AMTPTMI dan Berkahnya Malaise.

\section{Landasan Teori}

Istilah "sastra sejarah" muncul untuk menyebut karya-karya sastra (fiksi) yang di dalamnya terdapat fakta yang juga terdapat dalam sejarah. Menurut Ali (1963:8), sejarah berarti (1) jumlah perubahan-perubahan, kejadian-kejadian, dan peristiwa-peristiwa dalam kenyataan terakhir kita, (2) cerita tentang perubahan-perubahan tersebut, (3) ilmu yang bertugas menyelidiki perubahanperubahan tersebut. Sementara itu, menurut Daiches (dalam Budianta, 2008:7), sastra adalah suatu karya yang menyampaikan suatu jenis pengetahuan yang tidak bisa disampaikan dengan cara lain, yakni suatu cara yang memberikan kenikmatan yang unik dan pengetahuan yang memperkaya wawasan pembacanya. Liaw Yock Fang juga menyoroti perihal sastra sejarah ini. Akan tetapi, sastra sejarah yang didefinisikan Liaw Yock Fang adalah sastra sejarah dalam naskah-naskah klasik. Liaw (2011: 432) membagi sastra sejarah ke dalam dua bagian, yaitu (1) bagian yang bersifat mitos atau dongeng dan (2) bagian historis, teristimewa jika pengarang menceritakan hidupnya sendiri.

\subsection{AMTPTMI dan Berkahnya Malaise Sebagai Sastra Sejarah}

AMTPTMI dan Berkahnya Malaise memiliki dua unsur dalam sastra sejarah, yaitu fakta dan fiksi. Terdapat bagian historis seperti yang disebutkan Liaw Yock Fang. Dalam AMTPTMI, unsur historis tersebut bukanlah cerita mengenai pengarang, melainkan mengenai THHK. Dalam Berkahnya Malaise, cerita mengenai pengarang dapat ditemukan. Oleh karena itu, kedua karya ini dapat dikategorikan sebagai karya sastra sejarah.

\subsection{Komunikasi dalam Karya Sastra dan Teks Referensial}

Pada dasarnya, yang terjalin antara karya sastra dan pembaca adalah komunikasi. Ini pula yang diungkapkan oleh Hough (dalam Damono, 2010: 96), yaitu bahwa 
dalam pembacaan karya sastra ada dua dunia yang melaksanakan komunikasi: karya sastra dan pembaca. Sastra adalah fenomena sosial dan penciptaan karya sastra adalah tindak sosial. Dalam sosiologi sastra, ini disebut teori moral. Teori moral ini didasarkan atas pemikiran bahwa dengan menulis kita berniat untuk berkomunikasi sebab jika hanya ingin merenung-renung untuk diri sendiri saja, mengapa pula menulis dan menyebarluaskannya? Dari situlah kemudian muncul pernyataan bahwa sastrawan menyiarkan karyanya tentu dengan maksud berkomunikasi dengan sesamanya sebab penyiaran itu sendiri merupakan tindak sosial. Demikianlah sehingga terjadi dialog di antara keduanya, dengan pengarang sebagai "latar belakang".

Jan van Luxemburg dkk. (1989: 55) mengatakan bahwa apa yang berlaku bagi teks sastra berlaku juga bagi teks pada umumnya: teks terdiri atas bagian yang saling bertalian dan mempunyai hubungan dengan "konteks": pengarang, pembaca, dan dunia nyata. Berdasarkan hal itu van Luxemburg dkk. membuat pengelompokan jenis-jenis teks berdasarkan peranan faktor-faktor konteks di dalamnya, yaitu teks ekspresif, teks referensial, teks persuasif, dan teks retorik. Teks referensial dimaksudkan untuk memberi informasi tentang apa yang terjadi di dunia nyata.

Teks referensial yang memberi informasi mengenai dunia nyata berusaha melukiskan kenyataan sebagaimana adanya. Namun, tidak selalu tercipta gambaran yang objektif tentang kenyataan sebab seorang pengarang selalu menyajikan pandangannya sendiri tentang kenyataan itu dan ini tidak selalu sesuai dengan pandangan orang lain. Teks sastra tidak mengacu pada satusatunya dunia nyata secara langung, tetapi pertama-tama kepada dunia yang dibayangkan oleh teks. Dalam hal itu, teks memiliki sifat referensial yang khusus. Segala sesuatu yang diceritakan terjadi khusus dalam dunia novel. Teks novel referensial karena teks mengacu kepada dunia nyata dalam novel, yang selanjutnya mengacu pada dunia nyata yang sebenarnya. Dunia novel adalah paralel dengan dunia kita sendiri. Bila dunia nyata kita sendiri dapat kita temukan dalam dunia novel, kita akan tertarik pada teks semacam itu.

Hal inilah yang akan dibuktikan dalam bab berikutnya, yaitu bahwa AMTPTMI dan Berkahnya Malaise merupakan teks referensial dan di dalamnya terdapat komunikasi yang terjalin antara karya sastra dan pembaca dengan pengarang sebagai latar belakangnya.

\section{Metode Penelitian}

Paradigma positivisme mengembangkan metode penelitian kualitatif, dan positivisme mengembangkan metode kuantitatif (Sugiyono, 2009: 1). Metode kualitatif digunakan jika masalah penelitian belum jelas, masih remangremang atau mungkin malah masih gelap (Sugiyono, 2009: 22). Dalam penelitian kualitatif, pengumpulan data tidak dipandu oleh teori, tetapi oleh fakta-fakta yang ditemukan pada saat penelitian di lapangan. Oleh karena itu, analisis data yang dilakukan bersifat induktif berdasarkan fakta-fakta yang ditemukan dan kemudian dapat dikonstruksikan menjadi hipotesis atau teori.

Hasil penelitian kualitatif dapat digunakan di tempat lain manakala tempat tersebut memiliki karakteristik yang tidak jauh berbeda (Sugiyono, 2009: 3). Dalam penelitian ini, penulis akan menggunakan metode penelitian kualitatif. Teknik pengumpulan data yang dilakukan oleh peneliti adalah triangulasi teknik, yaitu teknik pengumpulan data yang bersifat menggabungkan dari berbagai teknik 
pengumpulan data dan sumber data yang telah ada (Sugiyono, 2009: 83). Peneliti akan menganalisis novel AMTPTMI dan Berkahnya Malaise dengan merujuk kepada sumber-sumber kepustakaan yang berhubungan dengan kesusastraan, baik klasik maupun modern. Secara lebih khusus, penulis akan menggunakan sumber-sumber kepustakaan mengenai kesusastraan Melayu Tionghoa.

4. Sejarah dan Fiksi Dalam Dua Novel Kwee Tek Hoay: Analisis Terhadap Novel Atsal Mulahnya Timbul Pergerakan Tionghoa yang Modern di Indonesia dan Berkahnya Malaise Sebagai Teks Referensial

Suryadinata (dalam Sidharta, 1989: 17) menyebut Kwee Tek Hoay sebagai penulis yang serba bisa. Karya-karya yang dibuat Kwee Tek Hoay meliputi novel, drama, dan buku-buku tentang filsafat agama. Sumardjo bahkan menyebutkan bahwa Drama di Boven Digoel adalah mahakarya Kwee Tek Hoay yang unggul sebagai roman dari segi jumlah halaman serta gagasangagasan yang dimasukkan di dalamnya.

Mengenai gagasan-gagasan Kwee Tek Hoay dalam novel-novelnya, ini agaknya merupakan pengaruh dari pekerjaan Kwee Tek Hoay juga. Kwee Tek Hoay adalah wartawan pada masa Perang Dunia I dan pernah membuat tulisan yang mendapat perhatian besar masyarakat kala itu yang diterbitkan di surat kabar Sin Po: Pemandangan Perang Dunia ke I Tahun 1914--1918 (1989: 266). Kemudian, pada tahun 1925, Kwee Tek Hoay menjadi kepala redaksi harian Sin Bin dan pada 1926-1932 menjabat sebagai pemimpin redaksi pada mingguan Panorama. Pada 1930-1932, ia juga menjabat sebagai pemimpin redaksi Moestika Panorama-kemudian berganti nama menjadi Moestika Romans-yang berisikan pelbagai rubrik, mulai dari artikel yang membahas urusan agama, wanita, keluarga, hingga politik.

Sebagai wartawan dan pemimpin redaksi berbagai majalah, Kwee Tek Hoay banyak membaca tulisan mengenai peristiwa-peristiwa yang tengah terjadi. Dari hasil pembacaannya tersebut dibuatlah tulisan mengenai peristiwa itu sehingga kita dapat menemukan Drama dari Merapi dan Drama dari Karakataoe yang merupakan novel dengan latar belakang peristiwa meletusnya Gunung Merapi dan Krakatau. Sumardjo (1989:99) juga mengatakan bahwa Kwee Tek Hoay amat kontekstual dengan lingkungan pembacanya. Beberapa novelnya ditulis bukan karena dorongan harus menulis, melainkan karena adanya peristiwa seperti meletusnya gununggunung, karena permintaan pembacanya, atau karena ia melihat ketidakberesan masyarakatnya.

Tampaknya, novel-novel Kwee Tek Hoay seperti Nonton Capgome dan Zonder Lentera merupakan novel-novel yang ditulisnya karena ia melihat ada ketidakberesan dalam masyarakat Tionghoa di Indonesia, khususnya para pemuda dan pemudinya. Gaya humor Kwee Tek Hoay juga dapat dilihat dalam novel-novel semacam ini selain, tentu saja, unsur didaktis yang sengaja dimasukkannya. Di lain sisi, Berkahnya Malaise merupakan salah satu novel Kwee Tek Hoay yang ditulis karena permintaan pembacanya.

Hampir dalam setiap novel Kwee Tek Hoay terdapat sebuah pengantar atau pendahuluan yang ditulisnya sendiri. Pengantar atau pendahuluan tersebut agaknya merupakan bentuk pertanggungjawaban Kwee Tek Hoay terhadap tulisannya yang dia rasa merupakan bagian dari perekaman situasi masyarakat pada masa itu. Kwee Tek Hoay menyadari bahwa yang dia tulis bukanlah sesuatu yang sekadar karangan belaka, melainkan sesuatu yang ditulis 
berdasarkan sesuatu lain yang terjadi di masyarakat. Ini juga boleh jadi merupakan pengaruh dari pekerjaannya dahulu sebagai wartawan yang dituntut memberikan tulisan-tulisan yang selain faktual juga dapat dipertanggungjawabkan.

Demikian juga halnya yang terdapat dalam AMTPTMI dan Berkahnya Malaise. Kwee Tek juga memberikan pengantar mengenai dua novelnya tersebut, bahwa yang dituliskannya dalam Berkahnya Malaise merupakan "beberapa pengecualian" dan yang dituliskannya dalam AMTPTMI merupakan "bentuk pelurusan terhadap anggapan yang keliru". Kisah-kisah yang dituliskannya dalam Berkahnya Malaise merupakan kejadian yang dia sebut benar-benar terjadi dan dituliskan untuk membuat para pembacanya merasakan sedikit kebaikan dari malaise yang dialami tokoh-tokohnya di dalamnya, termasuk dirinya. Sementara itu, kisahkisah yang dituliskan dalam AMTPTMI adalah uraian atau hikayat pergerakan modern Tiong Hoa Hwee Koan.

\subsection{Analisis Novel AMTPTMI Sebagai Teks Referensial \\ 4.1.1 Sejarah Tionghoa Hoa Hwee Koan}

Menurut Salmon (2010: 291), THHK muncul akibat keadaan dan tuntutan masyarakat Tionghoa yang dilatarbelakangi oleh makin kerasnya politik pemerintah Belanda terhadap Vrende Oosterlingen atau "Warga Asing Timur" dan terutama para warga Tionghoa. Politik tersebut membuat pemerintah kolonial Belanda memonopoli penjualan candu yang tadinya sepenuhnya diserahkan kepada para pedagang Tionghoa. Saat kehilangan hak istimewa dalam perdagangan, orang-orang Tionghoa terpaksa mencari penghasilan baru, apalagi dengan peraturan baru yang lebih diskriminatif. Masyarakat Tionghoa tidak berhak sama sekali untuk menduduki jabatan-jabatan administratif dan niat pemerintah dalam bidang pendidikan untuk masyarakat Tionghoa juga minim. Selalu ada hambatan bagi masyarakat Tionghoa untuk memperoleh pendidikan di sekolah Belanda.

Selain hal tersebut di atas, karena merasakan perlakuan tidak adil yang dilakukan oleh pemerintah Belanda, mulai dari hal perdagangan hingga tempat bermukim, semangat nasionalis mereka timbul. Mereka menyadari bahwa mereka adalah minortias yang ditindas. Kemudian, muncullah ide untuk membuat sebuah perkumpulan bagi orang-orang Tionghoa dan inilah yang menyebabkan THHK dibuat. THHK sendiri berarti "Perkumpulan Tionghoa".

Kapitein Lie Tjian Tjoen (1950: 7) dalam pengantarnya untuk Hari - Ulang ke-50 Tiong Hoa Hwee Koan Djakarta menyebutkan bahwa pendidikan orangorang Tionghoa di Indonesia pada awalnya didapatkan dari sekolah Gie Oh. Akan tetapi, lambat laun, dengan munculnya aliran baru di Tiongkok, sistem pendidikan untuk orang-orang Tionghoa di Indonesia pun berubah. Akhirnya, muncullah THHK sebagai sekolah Tionghoa modern yang pertama. THHK mendapat tunjangan rutin dari Kong Koan yang merupakan Dewan Kepala-Kepala Bangsa Tionghoa.

$$
\text { Nio Joe Lan (1940: }
$$
memperkirakan bahwa THHK berdiri pada 17 Maret 1900 atau 17 Djiegwee 2451. Keadaan Tiongkok yang begitu kacau pada tahun 1900 menyebabkan timbul pemikiran untuk membentuk perkumpulan baru di Batavia yang bersifat "lain dari pada yang lain" di atas dasar yang luas dan dengan mengajarkan kesopanan Tionghoa, terutama ajaran Khong Tjoe. Lie Kim Hok dan Lie Hin Liam adalah dua orang penggagas yang telah bekerja keras untuk 
mempropagandakan perkumpulan baru tersebut. Selain itu, terdapat 20 orangjumlah seluruhnya-yang mendirikan THHK, yaitu Phoa Keng Hek, Khoe A. Fan, Ang Sioe Tjiang, Oey Giok Koen, Oey Koen Ie, Tan Kong Tiat, Lie Him Liam, Nio Hoey Oen, Pjoe Lip Tjay, Khouw Kim An, Tan Tian Seng, Ouw Tiauw Soey, Ouw Sian Tjeng, Oen A Tjoeng, Lie Kim Hk, Khoe Siauw Eng, Tan Kim San, Khoe Hiong Pin, Khouw Lam Tjiang, dan Tjoa Yoe Tek. Khoe Siauw Eng adalah orang yang mengusulkan nama THHK.

\subsubsection{Atsal Mulahnya Timbul Pergerakan Tionghoa yang Modern di Indonesia sebagai Teks Referensial}

AMTPTMI berisi tujuh bab yang menjabarkan mulai dari asal mula munculnya THHK, orang yang mendirikannya, orang yang memegang jabatan tersebut, sampai pasal-pasal yang terdapat dalam perkumpulan tersebut. Akan tetapi, tentu tidak seluruh isi novel tersebut merupakan fakta. Terdapat juga fiksi atau tambahan-tambahan yang berasal dari Kwee Tek Hoay. Kedua bagian tersebut akan dijabarkan berikutnya.

Jan van Luxemburg dkk. (1989: 55) menyebutkan bahwa teks referensial yang memberi informasi mengenai dunia nyata berusaha melukiskan kenyataan sebagaimana adanya. Namun, tidak selalu tercipta gambaran yang objektif tentang kenyataan. Seorang pengarang selalu menyajikan pandangannya sendiri tentang kenyataan itu dan ini tidak selalu sesuai dengan pandangan orang lain. Teks sastra tidak mengacu pada satusatunya dunia nyata secara langung, melainkan pertama-tama kepada dunia yang dibayangkan oleh teks.

Dalam AMTPTMI, dunia nyata yang dirujuk oleh Kwee Tek Hoay adalah THHK. Kwee Tek Hoay ingin menunjukkan hikayat dari pergerakan Tionghoa modern tersebut berdasarkan data yang ia kumpulkan. Oleh karena itu, dalam AMTPTMI terdapat penyebutanpenyebutan tanggal-tanggal peristiwa penting, nama tokoh-tokoh penting, tujuan perkumpulan tersebut didirikan, sampai artikel-artikel di surat kabar yang membahas perkumpulan tersebut (THHK).

Dunia nyata dalam AMTPTMI yang merujuk kepada dunia nyata yang sebenarnya dapat dilihat dalam kutipan berikut.

"Pembrontakan Boxer di taon
1899-1900 ada kasudahan dari
haluan yang diambil oleh
pembesar-pembesar golongan
conservatief yang dikepalain oleh
Kokbo Tzu His, yang hendak usir
antero bangsa asing dari seluruh
Tiongkok, basmi semua orang
Kristen, dan tentangin segala
perobahan, supaya Tiongkok bisa
balik kombali dalem keadaan di
jeman dulu kutika bangsa asing
belon datang menggrecok." (hlm.
403)

Dalam kutipan di atas terlihat penyebutan Pemberontakan Boxer. Pemberontakan Boxer (義和團之亂 atau 義和團匪亂) adalah pemberontakan di Cina, dari November 1899 sampai dengan 7 September 1901, terhadap kekuasaan asing di sektor perdagangan, politik, agama, dan teknologi. Boxer merupakan pergerakan yang dimulai oleh petani Cina Utara yang berdasarkan atas semangat anti asing dan anti imperialis. Mereka menyerang orang asing yang membangun jalur kereta api dan melanggar Feng Shui, dan juga orang Kristen yang dianggap bertanggung jawab untuk dominasi asing di Cina. Pada Juni 1900, Boxer menyerang Beijing dan membunuh 230 orang non- 
Tionghoa. Banyak Tionghoa Kristen dan orang Katolik terbunuh di Provinsi Shandong dan Shanxi sebagai bagian dari pemberontakan. Slogan mereka adalah "扶清灭洋” (“Dukung Qing, hancurkan Barat"), mereka terus beraksi (http://warofweekly.blogspot.com/2010/1 1/pemberontakan-boxer.html diunduh pada 4 Juni 2012, pukul 17.08 WIB). Penyebutan peristiwa

Pemberontakan Boxer dalam AMTPTMI bukan sekadar penyebutan belaka. Kwee Tek Hoay ingin menunjukkan bahwa ketika THHK didirikan, situasi sosial dan politik di Tiongkok sedang begitu kacau. Selain itu, terdapat pula penyebutan tokoh-tokoh bersejarah, seperti Kaisar Kwang Hsu, Kokbo Tzu Hsi, dan Dr. Sun Yat Sen dalam AMTPTMI. Terdapat pula penyebutan peristiwa dirampasnya kekaisaran Kwang Hsu oleh Tzu Hsi, seperti yang terdapat dalam kutipan berikut.

"Tetapi ini pengharepan bagus tiada berjalan lama. Dan tanggal 22 September 1898 Kokbo Tzu Hsi sudah turun tangan dengen merampas kakwasaan dari tangannya Keizer Kwang Hsu yang dipenjara di satu pulo dalem taman astana, sedeng Kang Yoe Wei dan kawan-kawannya terancem dengen hukuman mati." (hlm. 402)

Hal ini juga disebutkan oleh Nio Joe Lan dalam kutipan berikut.

"Di Tiongkok di dalem taon 1875 moelai bertachta Keizer Kuang Hsu, satoe Keizer jang telah tjoba adaken perobahan-perobahan modern. Iapoenja kegioatan boeat adaken itoe perobahan-perobahan tida dapet kasetoedjoehannja Keiserin Tzu Hsi. Di dalem taon 1898 Keizer Kuang Hsu telah ditangkep di atas prentahnja
Keizerin Tzu Hsi dan sadjek itoe waktu ini Keizer jang penoeh dengen ideaal-ideaal modern tida banjak berarti poela sahingga ia wafat di dalem taon 1908." (1940: 4)

Agaknya penyebutan peristiwaperistiwa tersebut dalam AMTPTMI merupakan pengaruh dari pekerjaan Kwee Tek Hoay sebagai wartawan. Dalam pengantarnya dia juga menyebutkan bahwa AMTPTMI merupakan hikayat yang disusun berdasarkan catatan-catatan yang dia kumpulkan dan berdasarkan keterangan dari Phoa Keng Hek, Khouw Kim An, dan Khouw Lam Tjiang. Ini juga dapat dikatakan merupakan salah satu bentuk tanggung jawabnya sebagai seorang sastrawan sekaligus wartawan dalam memberikan informasi melalui karyanya, dalam hal ini AMTPTMI.

Selain penyebutan tanggal dan peristiwa penting serta nama tokoh-tokoh terkenal, terdapat juga penyebutan pasalpasal dan tujuan THHK didirikan. Terdapat pula kutipan-kutipan yang berasal dari surat pembaca yang diambil dari majalah Perniagaan. Tujuan THHK yang terdapat dalam AMTPTMI tertulis sama sebagaimana yang terdapat dalam Riwajat 40 Taon dari Tiong Hoa Hwe Koan - Batavia (1900-1939). Akan tetapi, Nio Joe Lan memberikan catatan dalam tulisannya tersebut bahwa tulisan aslinya dalam bahasa Melayu sudah tidak ada lagi. Boleh jadi, yang ditulis oleh Kwee Tek Hoay adalah hasil salinan dari tulisan tersebut yang juga diambil dari hasil pengesahan Sri Paduka Gouverneur-Generaal dd. 3 Mei 1901. Akan tetapi, Kwee Tek Hoay tetap menuliskannya dalam bahasa Melayu Tionghoa (bahasa lisan yang dipakai oleh orang-orang Tionghoa).

Sebagaimana telah disebutkan sebelumnya bahwa teks referensial yang 
memberikan informasi mengenai dunia nyata berusaha melukiskan kenyataan sebagaimana adanya. AMTPTMI melukiskan keadaan ketika THHK dibentuk serta memberikan gambaran mengenai berdirinya THHK. Namun, disebutkan pula bahwa dalam teks referensial tidak selalu tercipta gambaran yang objektif tentang kenyataan. Seorang pengarang selalu menyajikan pandangannya sendiri tentang kenyataan itu dan ini tidak selalu sesuai dengan pandangan orang lain. Kwee Tek Hoay pun demikian dalam AMTPTMI. Dalam AMTPTMI, terdapat pandanganpandangan dan pemikiran Kwee Tek Hoay. Pandangan-pandangan inilah yang merupakan bentuk komunikasi yang dilakukan Kwee Tek Hoay.

Pandangannya terhadap adat Tionghoa totok ikut diselipkan dalam AMTPTMI. Pandangannya tersebut sebenarnya merupakan sindiran pula untuk orang-orang Tionghoa totok di Jawa yang mencampuradukkan antara adat-istiadat dengan agama pribumi. Ini terlihat dalam kutipan berikut.

"Upacara sembayangan menurut perideran musim, memang dijalanken oleh orang Tionghoa di Java. Tapi, di sabelah itu, dalem rumah-rumah orang Tionghoa biasa dibikin juga sidekah Maulud dan laen-laen yang jadi kabiasaan Islam, dan ini sudah terjadi atas maunya sang Nyonya rumah yang turut juga adat kabiasaan dari ibu atawa nenenya yang beratsal dari pribumi.

Begitulah akhirnya adat kabiasaan, kapercayaan atawa agama dari bangsa Tionghoa di Java jadi sanget kalut dan memberatken, kerna dari fihak ayah totok marika diwarisken aturan yang berlaku di Tiongkok dengan tida bole dialpaken, oleh fihak ibu marika dirurukin sama aturan dan adat kabiasaan pribumi, dengen sama juga kukuh dan fanatieknya seperti dari fihak sang ayah." (hlm. 410411)

Selain itu, Kwee Tek Hoay juga memberikan informasi lain yang berbeda dengan yang diungkapkan Nio Joe Lan dan pemuka-pemuka dari THHK dan Kong Koan. Kwee Tek Hoay menuliskan bahwa tujuan utama THHK dibuat adalah untuk memajukan Khong Kauw. Ini terlihat dalam kutipan berikut.

"Dengen pengetahuannya yang luas tentang Khong Tjoe, maka kutika T.H.H.K. Batavia diberdiriken, Tuan Lie Kim Hok coba jalanken iapunya angen-angen aken adaken satu organisatie buat menyiarkan Khong Kauw. Itulah sebabnya maka gerakan dari T.H.H.K. ada berdasar atas pelajaran Khong Tjoe, yang bukan cumah digunaken untuk menjalanken segala macem perobahan, tapi juga aken sabagi penerangan batin bagi bangsa Tionghoa di Indonesia rata-rata. Aken sampeken ini maksud. Ada perlu anak-anak Tionghoa pelajarin huruf dan bahasa Tionghoa supaya bisa baca kitab-kitab Khong Kauw, maka T.H.H.K. musti berdiriken sekola-sekola Tionghoa dengen ondang guru-guru yang faham betul pelajarannya bukan saja mengajar huruf dan bahasa serta pelajaran Khong Kauw pada murid-murid, tapi juga diwajibken pada satiap bulan dua kalih saban cee-it dan cap-gouw, adaken khotbah atawa lazing aken menerangken ujar-ujar Khong Tjoe. Jadinya tujuan yang pertama dari sekola T.H.H.K. ada buat memajuken Khong Kauw, seperti juga sekola-sekola dari Zending 
buat memajuken agama Kristen."

(hlm. 416-417)

Dalam kutipan di atas, secara tidak langsung, terlihat pula perhatian Kwee Tek Hoay terhadap urusan keagamaan. Kata penerangan batin ditekankan olehnya dengan dicetak miring. Ini menunjukkan bahwa persoalan kebatinan menjadi titik berat dari Kwee Tek Hoay juga. Mungkin itu sebabnya ia menuliskan hal tersebut dalam AMTPTMI.

Seperti yang disebutkan oleh Gunadharma (dalam Sidharta, 1989: 266), Kwee Tek Hoay adalah pendiri yayasan Gabungan Tridharma Indonesia yang merupakan perkumpulan tiga agama, yaitu Khong $\mathrm{Hu} \mathrm{Cu}$, Dao, dan Budha. Kwee Tek Hoay juga telah banyak menulis esai keagamaan. Oey mengutip pernyataan Claudine Salmon (dalam Sidharta, 1989: 220) bahwa Kwee Tek Hoay tercatat telah menulis tidak kurang dari 60 judul berisikan esei mengenai pokok-pokok teologis, metafisik, mistik, kebatinan, kegaiban serta berbagai hal yang serupa. Oleh karena itu, ia menekankan penerangan batin sebagai bentuk apresiasinya terhadap THHK dan keagamaan.

\subsection{Analisis Novel Berkahnya Malaise Sebagai Teks Referensial} 4.2.1 Malaise di Indonesia

Malaise merupakan krisis pada akhir tahun 1920-an dan sepanjang tahun 1930-an (Wahyudi dalam Marcus, 2001: xxviii). Malaise atau economisch depressie menyebabkan bank-bank tutup, banyak perusahaan yang bangkrut, banyak karyawan yang diberhentikan, dan utang menumpuk. Salmon (2010: 442) menyebutkan bahwa dampak krisis pertama-tama dirasakan dalam penghitungan harga pasar bahan baku dan lebih khusus lagi pasar karet, timah, gula, dan tembakau. Di lain pihak, devaluasi Yen Jepang, yang terjadi pada tahun 1931, menimbulkan dampak membanjirnya produk Nippon di wilayah jajahan dan hal itu merugikan produk Eropa yang tidak dapat lagi bertahan menghadapi persaingan.

Jawa yang didominasi industri gula sangat terpukul. Sejak dihapuskannya pak opium dan pak lain, orang-orang Tionghoa kaya telah menginvestasikan modal mereka secara khusus dalam industri tersebut dan sebagian kecil dalam perdagangan kayu. Orang-orang Tionghoa tersebut termasuk yang paling kena dampak krisis tersebut. Perusahaanperusahaan batik pribumi dan Tionghoa pun terancam oleh invasi perusahaan katun Jepang. Sedikit demi sedikit semua cabang bidang usaha terkena dampaknya. Firma-firma Tionghoa makin bersaing dengan firma Eropa yang secara teknik lebih lebih baik perlengkapan dan organisasinya. Ini mengakibatkan kesulitan ekonomi bagi orang-orang Tionghoa di Indonesia.

\subsubsection{Berkahnya Malaise Sebagai Teks Referensial}

Dalam Berkahnya Malaise, tentu peristiwa malaise turut digambarkan, tetapi bukan penggambaran objektif seperti yang terdapat dalam berita-berita di surat kabar. Tentu ini yang membedakan sastra (cerita) dengan berita. Malaise dalam Berkahnya Malaise lebih bersifat referensial dibandingkan faktual. Ini sesuai dengan pengategorian van Luxemburg dkk. (1989: 55) mengenai teks referensial, yaitu bahwa teks referensial memberikan informasi mengenai dunia nyata dan berusaha melukiskan kenyataan sebagaimana adanya. Namun, pengarang tidak selalu menciptakan gambaran yang objektif tentang kenyataan tersebut.

Jika dikaitkan dengan Berkahnya Malaise, novel tersebut merupakan teks referensial yang ditulis oleh Kwee Tek 
Hoay berdasarkan peristiwa Malaise pada tahun 1920-an akhir sampai dengan sepanjang tahun 1930-an. Kwee Tek Hoay dalam hal ini tidak hanya mengacu kepada peristiwa malaise tersebut, melainkan memasukkan dunia idealnya dalam teks. Dunia novel adalah paralel dengan dunia kita sendiri (van Luxemburg dkk., 1989: 55). Bila dunia nyata kita sendiri dapat kita temukan dalam dunia novel, kita akan tertarik pada teks semacam itu. Berkahnya Malaise yang diterbitkan secara bersambung dalam majalah Moestika Romans cukup populer pada masa itu karena masyarakat menganggap bahwa hal yang terjadi dalam novel sebenarnya juga mereka alami.

Dunia yang digambarkan dalam Berkahnya Malaise adalah dunia yang berbeda dengan dunia nyata. Walaupun yang digambarkan adalah dunia dan tokohnya yang sedang mengalami malaise, dunia dalam Berkahnya Malaise adalah dunia ciptaan Kwee Tek Hoay. Oleh karena itu, Kwee Tek Hoay menuliskan kata berkahnya dalam judul. Ini menjadi semacam kontras bahwa yang ditampilkan Kwee Tek Hoay adalah kebaikan yang sebenarnya tanpa disadari terjadi saat malaise, sementara yang dirasakan oleh masyarakat adalah kesengsaraan malaise.

Yang dituliskan Kwee Tek Hoay dalam Berkahnya Malaise bukanlah suatu propaganda, melainkan suatu nasihat. Kwee Tek Hoay dalam hal ini juga berusaha menampilkan pengalamanpengalaman manusia yang universal. Walaupun dalam Berkahnya Malaise yang menjadi sorotan utama adalah peristiwa malaise, Kwee Tek Hoay sebenarnya berusaha memberikan pandangan "berkah" secara umum dalam memandang semua peristiwa yang dialami.

Kutipan di bawah ini menunjukkan bahwa dunia yang dirujuk Kwee Tek
Hoay dalam Berkahnya Malaise adalah dunia nyata. Penyebutan artikel dalam Koran Siang Po yang terbit pada 7 Juni 1933 mengenai malaise agaknya dilakukan juga untuk memberikan cerita yang jujur dan mendukung gagasan berkah yang ingin disampaikannya.

"Nyatalah Ho Tjoan Tjia sudah lupa pada kita punya nasehat yang duluan, maka aken bikin ia mendusin pada keadaan yang sabenernya, kita lantes sodorken Siang Po yang terbit 7 Juni 1933 lembar kadua pagina 1 kolom kaanem, dimana ada dimuat ini kabaran: PENGARUHNYA MALAISE ATAS KASEHATAN RAHAYAT...." (hlm. 231)

Kutipan tersebut diambil dari cerita "Bagimana Ho Tjoan Sudah Bisa Dapet Anak-Anak yang Sehat dan Panjang Umur". Anak-anak Ho Tjoan selalu sakit dan akhirnya meninggal dan ketika malaise datang, anak-anaknya jadi jauh lebih sehat karena hanya makan nasi dan sayur, tidak makan jajanan lain. Artikel yang "Pengaruhnya Malaise Atas Kasehatan Rahayat" dikutipnya dalam cerita tersebut merupakan bukti bahwa malaise juga dapat membawa berkah dan pengaruh baik. Jadi, Kwee Tek Hoay melakukan dua hal sekaligus, yaitu memberikan bukti otentik yang tercatat dalam sejarah mengenai pengaruh malaise serta memberikan pandangan berkah yang diyakininya.

Kwee Tek Hoay dalam Berkahnya Malaise dapat dikatakan sebagai pengarang yang jujur mengisahkan peristiwa-peristiwa yang terjadi dalam masyarakat di lingkungan sekitarnya. Ini terlihat secara khusus dalam bab 5, yaitu kisah "Bagimana Empe Lauw See Dji Telah Terbebas dari Kakuatirannya". Bab tersebut dibuka dengan kalimat berikut, "Di bawah ini ada satu surat yang kita 
trima dari Empe Lauw See Dji di Batavia, yang maskipun sudah berusia tinggi, masih sanget getol membaca Mustika Dharma dan Mustika Romans" (hlm. 205). Kemudian, seluruh kisah dalam bab tersebut merupakan surat yang dikirimkan Lauw See Dji untuk Kwee Tek Hoay. Surat tersebut ditampilkan seluruhnya apa adanya sehingga dapat terlihat juga bahwa yang bercerita adalah Lauw See Dji.

Kwee Tek Hoay, sebagaimana yang ditulis oleh Gunadharma (dalam Sidharta, 1989: 266), memang mendirikan sebuah mingguan Moestika Dharma yang khusus membahas persoalan agama, filsafat, dan teosofi. Penyebutan majalah tersebut mungkin juga merupakan salah satu promosi dagang yang tidak langsung. Pada dasarnya, karena Berkahnya Malaise awalnya merupakan kolom mingguan dalam Moestika Romans, yang tertera dalam Berkahnya Malaise juga tertera dalam Moestika Romans. Ini juga menunjukkan bahwa Kwee Tek Hoay ingin menunjukkan informasi yang sebenar-benarnya yang terjadi di dunia nyata. Surat Lauw See Dji pun demikian. Surat itu adalah informasi yang diberikannya kepada Kwee Tek Hoay, kemudian disampaikan lagi oleh Kwee Tek Hoay kepada pembaca. Dalam surat tersebut, yang terlihat adalah pandangan subjektif Lauw See Dji mengenai malaise yang membawa berkah untuk dirinya dan anaknya.

Mengenai pandangan subjektif Kwee Tek Hoay, dalam kutipan di bawah ini dapat terlihat gagasan Kwee Tek Hoay mengenai orang Tionghoa golongan tua.

"Sudah menjadi watek saumumnya antara orang Tionghoa golongan kuno yang kapan meliat satu macem pekerjaan yang bisa membri hatsil bagus atawa mengasih kadudukan tinggi, sabrapa bisa lantes mau ditiru. Dan cilakanya justru lantaran adanya ini watak, maka anak-anak Tionghoa kabanyakan yang dapet didikan atawa pelajaran menurut angen-angennya si orangtua, zonder dipusingin apa itu macem pelajaran ada mencolokin aanlegnya si anak atawa tiada." (hlm. 198)

Dalam kutipan tersebut terlihat bahwa Kwee Tek Hoay menyindir golongan tua (kuno) Tionghoa yang tidak bisa melihat orang lain sukses. Kwee Tek Hoay juga menuangkan pendapatnya mengenai anak-anak Tionghoa yang dipaksa orang tua mereka untuk menuntut suatu ilmu yang dianggap baik dan menguntungkan (membawa sukses) oleh orang tua mereka. Dengan tegas, Kwee Tek Hoay menggunakan kata cilakanya untuk menggambarkan situasi tersebut. Ini menjadi semacam penegasan bahwa menurutnya situasi atau keadaan semacam itu tidak membawa untung.

Pandangan lainnya juga ditunjukkan dalam "Bagimana Empe Tjoe Sudah Rayaken Taon Baru dengen Penuh Kagirangan". Dalam cerita tersebut, dikisahkan Empe Tjoe, salah seorang kenalan Kwee Tek Hoay, akhirnya bisa merayakan tahun baru bersama seluruh keluarganya lagi. Anakanaknya seluruhnya telah mapan setelah disekolahkan di luar negeri ketika ia masih menjadi hartawan besar. Karena anak-anaknya sekarang telah memiliki pekerjaan sendiri, Lauw Ay Tjoe hidup sendirian dan tidak pernah merayakan tahun baru bersama seluruh keluarganya. Akan tetapi, malaise membuat anakanaknya kembali kepadanya karena gaji mereka yang mendadak dikurangi dianggap tidak mencukupi kehidupan mereka. Hal ini membuat mereka kembali ke rumah orang tua mereka, Lauw Ay Tjoe, untuk menghemat biaya. Lauw Ay Tjoe tidak merasa dirugikan 
dan direpotkan karena hal tersebut, dia justru merasa senang. Kwee Tek Hoay mengungkapkan kesenangan Lauw Ay Tjoe tersebut sebagai berikut.

"'Wah, bo-eng betul sekarang,' aku menegor.

'Perkara bo-eng jangan ditanya lagi,' Ay Tjoe menyaut. 'Aku ampir tida bisa tidur lantaran ini anak-anak terlalu rebut, saban minuut musti ada yang berklai, menangis, bersurak atawa menjerit. Satiap hari musti masak nasi dua gantang, dan ka mana aku bertindak selalu dikrubungin oleh ini anak-anak. Puhun jeruk dan rambutan sampe gundil, iaorang sengget dan sambitin, sebab ini anak-anak kliwat nakal.'

Maski mulutnya seperti menyomel, tapi Ay Tjoe ucapken itu dengen tersenyum dan aer muka terang, satu tanda hatinya merasa senang." (hlm. 296)

"Ay Tjoe kaliatan tida merasa jengkel atawa kuatir hal bebrapa dari anak-anaknya blon punya pakerjaan, kerna katanya sekarang harga beras dan laen-laen makanan ada serba murah dan ia masih kuat piara pada marika semua. Sabaliknya ia merasa sanget girang dan bangga kerna ini sekalih bisa rayaken taon baru dengen berkumpul sama semua anak cucunya hal mana, kalu tida ada berkah dari malaise, pastilah selama-lamanya tida nanti bisa kajadian, kacuali kapan ia atawa istrinya hendak... brangkat tjoetshoa." (hlm. 297)

Terakhir, mengenai pandangan Kwee Tek Hoay dan perannya sebagai pengarang dalam Berkahnya Malaise, dapat kita lihat dalam "Bagimana Siem
Tik Too Tersedar dari Cacatnya". Dalam kisah tersebut Kwee Tek Hoay menampilkan dialognya dengan Tik Too sekaligus memberikan komentar atas dialog tersebut. Dalam hal ini, pengarang berperan sebagai pembentuk pandangan dan pemikiran pembaca. Hal ini dapat dilihat dalam kutipan berikut.

\section{"Kita musti akuin Piet Bak punya cingli ada lebih bener, tapi kita tau juga Tik Too punya tujuan pun bukannya jahat atawa "sengaja hendak menyilakaken," cumah ia kurang bisa mengimbangi laen orang punya kaadaan, yang ia selalu hendak persamaken dengen dirinya sendiri." (hlm. 248).}

\section{Simpulan dan Saran}

AMTPTMI dan Berkahnya Malaise merupakan teks referensial. Ini terbukti dengan terdapatnya kenyataan atau informasi mengenai dunia nyata, dalam hal ini adalah THHK dan peristiwa malaise. Kwee Tek Hoay berusaha untuk menampilkan informasi tersebut apa adanya. Namun, Kwee Tek Hoay juga menampilkan pandangannya sendiri dalam AMTPTMI dan Berkahnya Malaise. Pandangan-pandangan tersebut merupakan hasil pemikirannya mengenai peristiwa malaise yang dialami banyak orang serta persoalan yang melingkupi THHK. Hasil pemikiran tersebut merupakan bentuk komunikasi Kwee Tek Hoay dan karyanya. Kwee Tek Hoay dalam kedua novel tersebut membentuk pandangan dan pemikiran pembaca melalui komentar-komentarnya atas peristiwa yang ditulisnya.

Dunia yang terdapat dalam AMTPTMI dan Berkahnya Malaise adalah dunia yang paralel dengan dunia nyata. Informasi yang terdapat dalam AMTPTMI dan Berkahnya Malaise merupakan informasi yang berusaha disajikan apa adanya. Akan tetapi, yang 
dikatakan van Luxemburg dkk. ternyata benar. Pengarang pasti tidak dapat menampilkan seluruh informasi dengan objektif, Selalu akan muncul pandanganpandangan pengarang yang sifatnya tidak hanya subjektif, tetapi juga mengandung persuasi.

Pandangan-pandangan Kwee Tek Hoay mengenai berkah malaise dalam Berkahnya Malaise merupakan bentuk komunikasi yang dibangunnya dalam karya sastra agar, setelah pembaca melihat tulisan tersebut, pandangan pembaca juga berubah mengikuti pandangan yang ditulis olehnya. Dalam AMTPTMI, komunikasi tersebut dapat ditemukan berupa sindiran dan gagasan Kwee Tek Hoay tentang penerangan batin. Apa pun bentuk komunikasi tersebut, Kwee Tek Hoay telah berhasil menyajikan AMTPTMI dan Berkahnya Malaise sebagai karya yang tidak mengandung propaganda dan lebih bersifat didaktis.

Dalam penelitian selanjutnya, baik sekali jika peneliti melihat lebih jauh ke dalam semua novel karya Kwee Tek Hoay. Bukan hanya soal sejarah dan fiksinya yang dilihat, melainkan komunikasi sosial yang dilakukan Kwee Tek Hoay dalam setiap karya-karyanya. Ini menarik untuk diketahui cara penyampaian gagasan melalui karya sastra pada masa itu.

\section{Daftar Pustaka}

Ali, R. Moh. 1963. Pengantar Ilmu Sejarah Indonesia. Jakarta: Bhratara.

Budianta, Melani, dkk. 2008. Membaca Sastra. Jakarta: Indonesiatera.

Damono, Sapardi Djoko. 2010. Sosiologi Sastra: Pengantar Ringkas. Jakarta: Editum.
Kapitein Lie Tjian Tjoek. 1950. Hari Ulang ke-50 Tiong Hoa Hwee Koan Djakarta. Jakarta: Tiong Hoa Hwee Koan.

Liaw Yock Fang. 2011. Sejarah Kesusastraan Melayu Klasik ed. Riris K. Toha Sarumpaet. Jakarta: Yayasan Pustaka Obor Indonesia.

Marcus, A.S. dan Pax Benedanto. (ed.). 2001. Kesastraan Melayu Tionghoa dan Kebangsaan Indonesia. Jilid 4. Jakarta: Kepustakaan Populer Gramedia.

Nio Joe Lan. 1940. Riwajat 40 Taoen dari Tiong Hoa Hwe Koan Batavia (1900 - 1939). Jakarta (Batavia): Tiong Hoa Hwe Koan.

Salmon, Claudine. 2010. Sastra Indonesia Awal: Kontribusi Orang Tionghoa. Jakarta: Kepustakaan Populer Gramedia.

Sidharta, Myra. (ed.). 1989. 100 Tahun Kwee Tek Hoay: Dari Penjaja Tekstil sampai ke Pendekar Pena. Jakarta: Pustaka Sinar Harapan.

Sugiyono. 2009. Metode Penelitian Kuantitatif, Kualitatif, dan $R \& D$. Bandung: Alfabeta.

Sumardjo, Jacob. 2004. Kesusastraan Melayu-Rendah Masa Awal. Yogyakarta: Galang Press.

van Luxemburg, Jan, dkk. 1989. Tentang Sastra. Diterjemahkan oleh Akhdiati Ikram. Jakarta: Intermasa.

\section{Sumber Internet}

http://warofweekly.blogspot.com/2010/1

1/pemberontakan-boxer.html, "Pemberontakan Boxer" diunduh tanggal 4 Juni 2012 pukul 17.08 WIB. 